NBER WORKING PAPER SERIES

\title{
BANKER FEES AND ACQUISITION PREMIA \\ FOR TARGETS IN CASH TENDER OFFERS: \\ CHALLENGES TO THE POPULAR WISDOM ON BANKER CONFLICTS
}

\author{
Charles W. Calomiris \\ Donna M. Hitscherich \\ Working Paper 11333 \\ http://www.nber.org/papers/w11333
NATIONAL BUREAU OF ECONOMIC RESEARCH
1050 Massachusetts Avenue \\ Cambridge, MA 02138 \\ May 2005
}

The authors wish to thank Jon Byun, Jeff West, Stav Gaon and Derrick Wan for excellent research assistance. For helpful comments and discussions, we thank Lawrence A. Hamdan of Credit Suisse First Boston, Matthew B. Kratter, and Lawrence Glosten and Charles Jones of Columbia Business School. The views expressed herein are those of the author(s) and do not necessarily reflect the views of the National Bureau of Economic Research.

@ 2005 by Charles W. Calomiris and Donna M. Hitscherich. All rights reserved. Short sections of text, not to exceed two paragraphs, may be quoted without explicit permission provided that full credit, including $\odot$ notice, is given to the source.

Banker Fees and Acquisition Premia for Targets in Cash Tender Offers: Challenges to the Popular Wisdom on Banker Conflict 
Charles W. Calomiris and Donna M. Hitscherich

NBER Working Paper No. 11333

May 2005

JEL No. G24, G28, G34

\section{ABSTRACT}

We analyze data on fees paid to investment bankers and acquisition premia paid for targets in cash tender offers. Our results are broadly consistent with the predictions of a benign view of the role of investment banks in advising acquisition targets. Fees to investment banks are correlated with attributes of transactions and target firms in ways that make sense if banks are being paid for processing information. The more contingent (and, therefore, risky) the fees, the higher they tend to be, all else held constant. Variation in acquisition premia also can be explained by fundamental deal attributes. Contrary to the jaundiced view of fairness opinions, greater fixity of fees is not associated with higher acquisition premia, and there is no evidence that investment banks are suborned by acquirors with whom they have had a prior banking relationship.

Charles W. Calomiris

Graduate School of Business

Columbia University

3022 Broadway Street, Uris Hall

New York, NY 10027

and NBER

cc374@columbia.edu

Donna M. Hitscherich

Columbia Business School

3022 Broadway

New York, NY 10027

dmh9@columbia.edu 


\section{Introduction}

Investment banking practices recently have become the subject of intensifying scrutiny from regulators and the investment community, each of which has raised questions concerning the efficacy of certain advisory services offered by investment banks - specifically, fairness opinions. This scrutiny largely has been based on anecdotal observations. ${ }^{1}$ This article provides empirical evidence germane to those questions. We explain why and how fairness opinions are rendered, and how target companies pay investment banks for this advisory service. We explore potential incentive problems associated with the structure of investment banker fees and other potential conflicts of interest on the part of the investment banker from an empirical perspective. In so doing, we construct a new database on firm and deal characteristics for friendly, two-step cash acquisitions. Our data measure characteristics of target firms and transactions, fees paid to investment bankers, and premia paid to shareholders of the target company in connection with the acquisition, and explore the connections among these variables to cast light on this neglected area of corporate finance.

We consider empirical implications of the views expressed by both the critics and the defenders of investment banking practices relating to the provision of fairness opinions. We analyze the determinants of investment bank fees and acquisition premia. We find no evidence in support of the view that the typical investment bank fee structure engenders conflicts of interest detrimental to the target shareholders. Nor do we find any

\footnotetext{
${ }^{1}$ See, e.g, Wall Street Journal, December 29, 2004 summarizing the popular criticisms leveled at fairness opinions and observing that the investment banks that render the fairness opinion are often the advisors who arranged the transaction in the first instance and whose fees depend on the successful consummation of the transaction. See also Bebchuk and Kahan (1989) noting that fairness opinions are "problematic" because investment banks have "substantial discretion in rendering such opinions" and the conflicts of interest faced by the investment bank "lead them to use their discretion to render pro-management fairness opinions."
} 
evidence consistent with the view that bank advisory services to target firms are adversely affected by pre-existing business relationships between bankers and would-be acquirors. Furthermore, our analysis of variation in fees and acquisition premia indicates, among other things, that (1) the variation in fees paid to investment banks by target firms reflects differences in the fundamental costs of valuing targets, and (2) the variation in acquisition premia paid to target shareholders reflects target and transaction characteristics. With respect to the latter, target characteristics include volatility, leverage, and possibly other transaction characteristics that are less significant statistically, including the existence of employment contracts entered into by acquirors to retain target firm management (which are associated with higher acquisition premia). ${ }^{2}$

\subsection{What is a fairness opinion? Why and how are they rendered?}

When a public company is the target in an acquisition scenario, the target company's board of directors commonly will engage the services of a financial advisor generally, an investment bank. In connection with this retention, the board of directors of the target company and the investment bank execute an engagement letter. The engagement letter delineates, among other things, (a) the services the investment bank will provide to the board of directors on behalf of the target company in connection with a proposed transaction and (b) the amount and terms of payment of the fee for such services.

Typically, one of the services offered by an investment bank is an opinion as to the fairness to the target shareholders, from a financial point of view, of the transaction

\footnotetext{
${ }^{2}$ Our paper does not address the effects of "golden parachutes" that the target company had in place prior to consummation of the transaction.
} 
proposed to be undertaken by the target board of directors (a "fairness opinion").

Fairness opinions share several important characteristics. First, the fairness opinion is issued in the form of a letter addressed to the target board of directors and is filed as an exhibit to the relevant Securities and Exchange Commission ("SEC") filings made by the target in connection with the proposed transaction. Second, the fairness opinion is dated as of the date it is rendered to the target board of directors (generally the date the target board of directors holds its meeting to vote on the proposed transaction) and speaks only as of such date with no duty (unless the engagement letter specifically provides otherwise) on the part of the investment bank to update ("bring-down") the opinion to a later date. Third, the fairness opinion speaks only to the fairness of the transaction from "a financial point of view" and does not (a) opine that the consideration to be received by the target shareholders in the proposed transaction represents the highest or best price available; (b) address the merits of the transaction or the decision of the board of directors of the target to proceed with the transaction, relative to other possible business strategies; or (c) assume any responsibility for independent verification of the publicly available information respecting the target or the information furnished by the management of the target to the investment bank in connection with its valuation. Finally, the fairness opinion addressed to the target board of directors expressly states that it does not constitute a recommendation to the target shareholders with respect to the actions necessary to be undertaken by such shareholders for the consummation of the proposed transaction.

Despite the lack of any legal imperative, virtually all boards of directors of public target companies secure fairness opinions before proceeding with a transaction. The 
basis of securing such fairness opinions is traced by many back to the Delaware Supreme Court's decision in Smith v. Van Gorkom, 488 A.2d 858 (Del. 1985). Under the reasoning of Van Gorkom and state statutory authority, including Delaware (8 Del. C. $\S$ 141(e)) providing that boards of directors may rely on professional opinions of others assuming such reliance is reasonable, the fairness opinion may serve as evidence that the board of directors has fulfilled its fiduciary duty of care in assessing the financial terms of the proposed transaction.

\subsection{How do targets pay for fairness opinions?}

The fee paid by the target company to the investment bank in connection with a tender offer may be found in Item 5 of the Solicitation/Recommendation Statement on Schedule 14D-9 ("Schedule 14D-9") filed by the target with the SEC. The fee to be paid to the investment bank frequently is (a) expressed as a percentage of the overall value of the transaction (defined as the value paid by the acquiror for the equity of the target plus the value of the liabilities assumed) and (b) payable upon the consummation of the transaction (referred to herein as a "Contingent Fee"). In certain instances, the target board of directors may agree to pay the investment bank a fee irrespective of whether the transaction is consummated, which fee would typically represent a small portion of the total fee payable if a transaction were consummated, but may on occasion be the only fee payable to the investment bank. These non-contingent fees may be in the nature of a retainer fee payable either upon execution of the engagement letter or over a period of months during which the investment bank is retained by the target (a "Retainer Fee") or an opinion fee payable when the investment bank is prepared to render a fairness opinion 
with respect to the proposed transaction (an "Opinion Fee"). The Retainer and Opinion Fees collectively will be referred to herein as "Fixed Fees." As noted above, as a percentage of overall transaction value, Fixed Fees generally are much smaller than Contingent Fees and accordingly, an investment bank earning a Contingent Fee stands to make considerably more fee income if the transaction is consummated. Contingent Fees are often referred to in the investment banking industry as "Success Fees." In certain instances where the engagement letter provides for a Fixed Fee in addition to the Contingent Fee, the Fixed Fee (to the extent previously paid to the investment bank) may be creditable against the Contingent Fee.

There are three common forms of Contingent Fee arrangements: (1) contingent payment expressed as a constant percentage of the overall transaction value (a "Constant Percentage Fee"); (2) contingent payment expressed as an aggregate dollar amount that does not vary based on the size of the transaction ("Constant Dollar Fee") and (3) contingent payment expressed as a sliding scale percentage based on the size of the transaction ("Variable Percentage Fee"). In the sale of a target company, the most common form of Contingent Fee is the Constant Percentage Fee. The Variable Percentage Fee is less common and generally limited to smaller or private company transactions. The Constant Dollar Fee is a more common fee arrangement for the investment banker to the acquiror inasmuch as, the acquiror may not wish to "reward" its investment banker in the form of a higher cash fee as the purchase price to be paid by the acquiror increases.

Investment banker fees in merger and acquisition transactions are highly negotiable. As we will show in Section 2 below, fee amounts vary considerably. An 
investment bank may "pitch" its services to the target board of directors based on, among other things, the investment bank's M\&A experience both generally and in the target's industry. M\&A "league tables" ranking investment banks based on their participation in announced M\&A transactions over a given period are often employed for this purpose. Ultimately, the target board of directors will pay the investment bank based on the target board's perception of the value the investment banker will deliver to the board of the target in connection with the transaction. ${ }^{3}$ In this regard, the then co-head of global mergers and acquisitions at Credit Suisse First Boston observed, "It is not just the deal assignments per se, but the quality of your role that is driving your fees." Wall Street Journal, December 11, 2003.

\subsection{Contingent fees: conflict or alignment of interests?}

The fact that investment banks typically are paid the bulk of the fee upon consummation of a transaction has been criticized by some observers as potentially giving rise to a conflict of interest between the investment bank and its client - the target board of directors. According to what we will call the "jaundiced" view of Contingent Fees, making fees contingent on consummation of the transaction (and by extension the rendering of a fairness opinion as a de facto pre-condition to consummation of a transaction) encourages the investment banker to "do what it takes" to opine favorably as to the fairness of the proposed transaction, in order to receive contingent compensation.

\footnotetext{
${ }^{3}$ See also comments of a former general counsel of an investment bank observing that the banker's fee "exorbitant or reasonable" is the product of many factors, including size and importance of the transaction, and "the benefits the company-client perceives or, with persuasion, can be made to perceive it is receiving." Panel Discussion Chaired by Arthur H. Rosenbloom (Spring 1991).
} 
In determining whether to address this concern from a regulatory perspective, on November 11, 2004, the NASD issued Notice to Members 04-83-Request for Comment on Whether to Propose New Rule That Would Address Conflicts of Interest When Members Provide Fairness Opinions in Corporate Control Transactions ("NASD Notice 04-83”). In response to the NASD's request for comment on the proposal, one prominent activist institutional investor observed that the contingent fee structure creates a "very large incentive for an investment bank to find that a transaction is fair regardless of the circumstances, when the bank will receive the bulk of its fee only if the transaction is successful" (Response of California Public Employees' Retirement System (CALPERS), dated February 1, 2005 to NASD Notice 04-83). Another response cast doubt on "how any board of directors can rely on a fairness opinion provided by an investment bank when the lion's share of that bank's fee is contingent on the underlying transaction closing." (Response of American Federation of Labor and Congress of Industrial Organizations (“AFLCIO”), dated January 10, 2005 to NASD Notice 04-83).

Additional causes for concern about the objectivity, and therefore, the utility of fairness opinions have been raised. For example, an investment bank may favorably opine on an otherwise financially inadequate offer based on a desire to please the wouldbe acquiror of the target because the ultimate acquiror of the target will be in a position to offer the target's investment banker additional fee generating transactions. Moreover, the existence of a pre-existing relationship between the would-be acquiror and the target's investment bank further could serve to cloud the objectivity of the investment bank as it renders its fairness opinion. 
Despite the foregoing, there are powerful arguments that weigh against what we have called the "jaundiced" view of fairness opinions. According to the alternative "benign" view, Contingent Fees that are proportional to the value of the acquisition serve to align the incentives of the investment banker with its client since the higher the price paid by the acquiror the higher the fee received by the investment bank. Accordingly, investment banks have an incentive to advise against accepting financially inadequate offers if the investment banks are able to share in the gains produced by accepting higher offers.

Furthermore, the critical positions expressed by CALPERS and the AFLCIO, while commonly echoed by commentators and the popular press, fail to take into account other important practical considerations. First, experience shows that the Contingent Fee structure typically is the preferred structure chosen by target boards of directors, who should seek to align the interests of the investment banker with those of the shareholders (See Response of each of The Association of the Bar of the City of New York (the “ABA”), dated February 1, 2005 and Securities Industry Association, dated February 1, 2005 to NASD Notice 04-83).

Second, investment banks bear reputational and legal risks when offering fairness opinions. An investment bank that routinely opines favorably on an otherwise financially inadequate offer will find it hard to attract future clients, and runs the risk of lawsuits.

Third, an otherwise financially inadequate transaction that collapses under shareholder opposition after the fairness opinion is rendered (generally at the meeting of the board of directors where the board votes on whether to proceed with the proposed transaction) will generate no contingent fees for the investment banker. 
Finally, the fact that the publicly observed fairness opinions are typically favorable ignores the unobservable but real world iterative process involved in rendering a fairness opinion and does not imply that favorable opinions are rendered with that same high frequency. The head of mergers and acquisitions at a major law firm framed the issue plainly stating that " $[\mathrm{t}]$ he reason you don't see unfairness opinions is that those deals won't get done." Wall Street Journal, January 24, 2005. In practice, if the banker is having difficulty reaching a favorable conclusion as to the fairness of the transaction from a financial point of view, the banker will alert the board to this fact in advance of the board meeting and "those transactions are typically either renegotiated or abandoned [and] [f]or obvious reasons, this occurs much more frequently than is generally known or apparent." (Response of the ABA, dated February 1, 2005 to NASD Notice 04-83).

\section{4 "Testing" the jaundiced and benign views of fairness opinions.}

Our empirical analysis does not purport to construct a full-blown structural model of investment banker fees or target acquisition premia. Instead, we perform simple means comparisons and regression analyses to measure whether patterns of association in the data appear to be more consistent with the implications of the benign or the jaundiced views.

We focus on six categories of empirical implications of the benign and jaundiced views of fairness opinions, as set forth below.

First, according to the benign view, the amount of fees paid to the investment bank should reflect the difficulty of processing information about the target necessary for the bank to form a view as to the valuation of the target and the likelihood of an ultimately 
successful sale transaction. Consequently, according to the benign view, investment banker fees should increase with attributes of the firm or the transaction that make it inherently more difficult to make such an assessment of the target. Those informationcost attributes include the (a) timing of the transaction (e.g., targets in industries whose stock performance exceeds the broader market are easier to sell); (b) attributes of the target (e.g., firms perceived by the market to be high risk are harder to value); and (c) prior relationship between the target and the investment bank (e.g., firms well-known to the investment banker are easier to value).

Second, according to the benign view, transactions that are perceived to be more complicated to complete (involving multiple bidders or an auction process) should command a higher fee.

Third, according to the benign view, because of the risks borne by investment bankers from Contingent Fees, the greater the proportion of the fee that is contingent, the greater the amount of the fee.

Fourth, according to the benign view, acquisition premia reflect the franchise value of the target, including both its tangible and intangible assets.

Fifth, according to the jaundiced view, transactions where a greater proportion of investment banker fees are fixed (as opposed to contingent) should, on average, display higher acquisition premia (since, according to the jaundiced view, Contingent Fee structures encourage investment banks to permit otherwise financially inadequate deals to go forward).

Sixth, according to the jaundiced view, a prior relationship between the investment bank and the acquiror should result in a lower acquisition premium, holding 
other factors constant. In contrast, according to the benign view, the acquisition premium should reflect the fundamental attributes of the target and the transaction, not the structure of the investment banker fee or any prior relationship between the investment bank and the acquiror.

The remainder of our paper explores these six implications of the benign and jaundiced views, first from the perspective of simple differences in means, and second, from the perspective of regression analyses. Section 2 discusses the construction of our dataset, the definitions of the variables employed in our analysis, and summary statistics. Section 3 presents our regression findings. Section 4 concludes.

\section{Data}

\subsection{Sample}

We examine transactions in excess of $\$ 100$ million in value, which were announced between 1994 and 2002 and completed, where the consideration was solely cash, and where the acquisition was effected pursuant to a friendly, two-step transaction. We focus on cash transactions because in such situations the evaluation of the consideration received by the target shareholders is clearly known ex ante. In a cash transaction the target shareholders will not share in any of the "upside" of the ultimate merger as could be argued they would in the case where the target shareholders receive stock of the acquiror.

A friendly, two-step transaction is a transaction approved by the target board of directors pursuant to a first-step tender offer (wherein the acquiror tenders for all, or a number of target shares sufficient for the acquiror to effect a subsequent merger of the 
target into an acquisition subsidiary of the acquiror, whereby the target becomes a wholly owned subsidiary of the acquiror), and a second-step merger between the target and the acquisition subsidiary. We focus on friendly, two-step transactions because that structure generally minimizes the time from announcement to consummation of the transaction. The greater speed of consummation reflects the fact that the acquiror does not need target shareholder approval for the second-step merger. This feature of friendly, two-step transactions obviates to a great extent the potential concern over the "staleness" of an investment banker's fairness opinion at the time the target shareholders tender their shares pursuant to the offer.

The transactions in the sample were identified based on information set forth in the database of Securities Data Company (“SDC”). To be included in the sample, the transaction needed to satisfy the following criteria:

(1) The transaction was announced between 1994 and 2002 and completed.

(2) The target was a U.S. public company.

(3) The transaction value was in excess of $\$ 100$ million.

(4) The consideration paid to the target shareholders pursuant to the tender offer consisted solely of cash and the transaction was effectuated pursuant to a friendly twostep deal.

(5) The transaction was not a (a) "going private transaction" within the meaning of Rule 13e-3 of the Securities Exchange Act of 1934, as amended; (b) management buy-in or management buy-out or (c) leveraged buy-out.

(6) The target company had the following SEC filings available on Edgar: (a) Schedule 14D-9; (b) Schedule 14F and (c) Proxy Statement for the regularly scheduled annual 
meeting of the target shareholders for the most recent meeting of target shareholders before the consummation of the transaction.

All calculations of the fee payments to the investment banker were based on the fee information reported in Item 5 of the target company's Schedule 14D-9 and SDC data. The acquisition premia for the 170 transaction observations were as reported by SDC and calculated as the per share offer price for the target equity divided by the stock price of the target four weeks prior to the announcement of the transaction minus one.

Application of the above selection criteria yielded a sample of 170 transactions. For each of the transactions so identified, information on a number of attributes of the transaction was obtained, as described in the Table [2.1]. Table [2.1] also provides the labels for the regressors used in the tables that report summary statistics in the remainder of Section 2, and in the investment bank fee (IBFEE) and acquisition premium (ACQPREM) regression models reported in Section 3. 
Table 2.1: Regressor Definitions

\begin{tabular}{|c|c|c|}
\hline Variable & $\begin{array}{c}\text { Variable } \\
\text { Designation }\end{array}$ & Description \\
\hline $\begin{array}{l}\text { Acquisition Premium offered by } \\
\text { Acquiror to Target Shareholders }\end{array}$ & ACQPREM & $\begin{array}{l}\text { Per share offer price for target equity divided by the stock price of the } \\
\text { target four weeks prior to announcement of transaction minus one. }\end{array}$ \\
\hline $\begin{array}{l}\text { Fee paid by Target's Board of } \\
\text { Directors to Target's Investment } \\
\text { Banker }\end{array}$ & IBFEE & $\begin{array}{l}\text { Target investment banker's fee computed as a percent of total } \\
\text { transaction value (amount paid for target equity plus assumed liabilities } \\
\text { as computed by SDC) based on information in target's Schedule 14D-9 } \\
\text { and SDC. }\end{array}$ \\
\hline Size of Target & $\operatorname{Ln}($ Size $)$ & Natural log of the total assets of the target as reported by SDC. \\
\hline $\begin{array}{l}\text { No Solicitation Language in } \\
\text { Banker Fairness Opinion }\end{array}$ & NoSolicitation & $\begin{array}{l}\text { Dummy variable based on text of banker's fairness opinion in Schedule } \\
14 \mathrm{D}-9 \text {. Variable takes a value of } 1 \text { if the investment bank fairness } \\
\text { opinion states banker did not solicit bids; otherwise variable takes a } \\
\text { value of } 0 \text {. }\end{array}$ \\
\hline $\begin{array}{l}\text { Nature of Sale Process } \\
\text { Preceding Consummation of } \\
\text { Transaction }\end{array}$ & ModeSale & $\begin{array}{l}\text { Dummy variable based on disclosure in target's Schedule 14D-9. } \\
\text { Variable takes a value of } 1 \text { if either an auction took place or the target } \\
\text { received multiple indications of interest during the course of the } \\
\text { transaction; otherwise variable takes a value of } 0 .\end{array}$ \\
\hline $\begin{array}{l}\text { M\&A Market Share of Target } \\
\text { Investment Banker }\end{array}$ & IB_Rank & $\begin{array}{l}\text { Target investment banker's three-year average M\&A advisor ranking as } \\
\text { reported by Investment Dealers Digest for the three-year period prior to } \\
\text { the transaction with lower numerical rankings implying a greater M\&A } \\
\text { market share. }\end{array}$ \\
\hline Volatility of Target Stock Price & Vol & $\begin{array}{l}\text { Volatility of target stock price returns based on latest twelve months } \\
\text { prior to the transaction announcement. }\end{array}$ \\
\hline $\begin{array}{l}\text { Performance of Industry of } \\
\text { which Target is a Member }\end{array}$ & PeerBroad & $\begin{array}{l}\text { Most recent indexed performance of target's peer group of stocks } \\
\text { divided by indexed performance of a broad index over the same period } \\
\text { as set forth in the target's most recent proxy statement or Schedule } 14 \mathrm{f} \text {. }\end{array}$ \\
\hline $\begin{array}{l}\text { Prior Relationship of Target's } \\
\text { Investment Banker with ultimate } \\
\text { Acquiror of Target }\end{array}$ & IBOthBus(Acquiror) & $\begin{array}{l}\text { Dummy variable based on disclosure in target's Schedule 14D-9. } \\
\text { Variable takes a value of } 1 \text { if target's investment banker had a prior } \\
\text { relationship with the acquiror; otherwise variable takes a value of } 0 \text {. }\end{array}$ \\
\hline $\begin{array}{l}\text { Prior Relationship of Target's } \\
\text { Investment Banker with Target }\end{array}$ & IBOthBus(Target) & $\begin{array}{l}\text { Dummy variable based on disclosure in target's Schedule 14D-9. } \\
\text { Variable takes a value of } 1 \text { if target's investment banker had a prior } \\
\text { relationship with the target; otherwise variable takes a value of } 0 .\end{array}$ \\
\hline $\begin{array}{l}\text { Bonus Payments to Target } \\
\text { Management in connection with } \\
\text { Sale Process }\end{array}$ & Bonus & $\begin{array}{l}\text { Dummy variable based on disclosure in target's Schedule } 14 \mathrm{D}-9 \text { or } \\
\text { Schedule } 14 \mathrm{f} \text {. Variable takes a value of } 1 \text { if management received a } \\
\text { bonus payment (excluding payments pursuant to existing Golden } \\
\text { Parachutes) related to consummation of a transaction; otherwise variable } \\
\text { takes a value of } 0 .\end{array}$ \\
\hline $\begin{array}{l}\text { Contracts Entered into by the } \\
\text { Acquiror with Target } \\
\text { Management in connection with } \\
\text { the Transaction }\end{array}$ & EmpContr & $\begin{array}{l}\text { Dummy variable based on disclosure in target's Schedule } 14 \mathrm{D}-9 \text { or } \\
\text { Schedule } 14 \mathrm{f} \text {. Variable takes a value of } 1 \text { if acquiror entered into an } \\
\text { employment contract with target management as part of the transaction; } \\
\text { otherwise variable takes a value of } 0 \text {. }\end{array}$ \\
\hline $\begin{array}{l}\text { Proportion of Leverage in the } \\
\text { Target's Capital Structure }\end{array}$ & Leverage & $\begin{array}{l}\text { Ratio of debt to total capitalization of the target based on market value } \\
\text { of the target's equity four weeks prior to the transaction and implied } \\
\text { debt of the target as reported by SDC. }\end{array}$ \\
\hline $\begin{array}{l}\text { Significant non-Officer/Director } \\
\text { Shareholders of Target }\end{array}$ & Non-O/D_w/5\% & $\begin{array}{l}\text { Number of } 5 \% \text { beneficial equity holders of the target who are not } \\
\text { officers or directors of the target as disclosed in target's most recent } \\
\text { proxy statement or Schedule 14f. }\end{array}$ \\
\hline $\begin{array}{l}\text { Officer and Director Equity } \\
\text { Ownership of Target }\end{array}$ & O/D_Oship & $\begin{array}{l}\text { Percentage of target equity beneficially owned by target's officers and } \\
\text { directors as disclosed in target's most recent proxy statement or } \\
\text { Schedule 14f. }\end{array}$ \\
\hline $\begin{array}{l}\text { Target Shareholder support for } \\
\text { Transaction }\end{array}$ & ShrhAgmt & $\begin{array}{l}\text { Dummy variable based on disclosure in target's Schedule 14D-9. } \\
\text { Variable takes a value of } 1 \text { if target shareholders have entered into a } \\
\text { voting agreement with acquiror in support of the transaction; otherwise } \\
\text { variable takes a value of } 0 .\end{array}$ \\
\hline $\begin{array}{l}\text { Percent of the Target Investment } \\
\text { Banker Fee that is Non- } \\
\text { contingent }\end{array}$ & FixedFee_Pct & $\begin{array}{l}\text { Percentage of the target investment banker's fee that is not contingent } \\
\text { on the outcome of the transaction, includes retainer fee plus any fairness } \\
\text { opinion fee each as set forth in Schedule 14D-9. }\end{array}$ \\
\hline M\&A Market Activity Levels & MarkAct & $\begin{array}{l}\text { Level of dollar volume worldwide announced M\&A activity for the } \\
\text { transaction year divided by corresponding level of M\&A activity in } \\
1994 .\end{array}$ \\
\hline Residual of the Fee Equation & IBFee_Res & Regression residual from equation 4 in Table [3.2] \\
\hline
\end{tabular}




\subsection{Summary statistics}

We divide the summary statistics into three categories of variables, which are organized by transaction value: (1) information about investment banker fees (IBFEE) and acquisition premia (ACQPREM) are described in Table [2.2a]; (2) target characteristics appear in Table [2.2b]; and (3) transaction characteristics are reported in Table $[2.2 \mathrm{c}]$.

Table 2.2a: Target Investment Banker Fee and Acquisition Premia

\begin{tabular}{|l|c|c|c|c|c|c|c|}
\hline $\begin{array}{l}\text { Variable/Transaction } \\
\text { Value }\end{array}$ & $\begin{array}{c}\text { Sample } \\
\text { Statistics }\end{array}$ & $\begin{array}{c}\$ 100- \\
\$ 149\end{array}$ & $\begin{array}{c}\$ 150- \\
\$ 199\end{array}$ & $\begin{array}{c}\$ 200- \\
\$ 299\end{array}$ & $\begin{array}{c}\$ 300- \\
\$ 499\end{array}$ & $\begin{array}{c}\$ 500- \\
\$ 999\end{array}$ & $\begin{array}{c}\$ 1,000 \\
\text { and Above }\end{array}$ \\
\hline $\begin{array}{l}\text { Number of } \\
\text { observations (N) }\end{array}$ & 170 & 36 & 29 & 33 & 31 & 19 & 22 \\
\hline $\begin{array}{l}\text { Fee Dollar Amount } \\
(\$ M M) \text { mean }\end{array}$ & $\$ 4.24$ & $\$ 1.50$ & $\$ 2.22$ & $\$ 2.76$ & $\$ 3.94$ & $\$ 6.44$ & $\$ 12.15$ \\
\hline Min & $\$ 0.15$ & $\$ 0.15$ & $\$ 0.20$ & $\$ 1.22$ & $\$ 0.55$ & $\$ 1.00$ & $\$ 4.00$ \\
\hline Max & $\$ 25.21$ & $\$ 3.20$ & $\$ 5.30$ & $\$ 4.50$ & $\$ 8.87$ & $\$ 19.30$ & $\$ 25.21$ \\
\hline Standard Dev & 4.46 & 0.78 & 1.31 & 0.81 & 2.01 & 3.74 & 6.80 \\
\hline IBFEE mean & $1.04 \%$ & $1.17 \%$ & $1.27 \%$ & $1.17 \%$ & $0.97 \%$ & $0.88 \%$ & $0.56 \%$ \\
\hline Min & $0.12 \%$ & $0.13 \%$ & $0.12 \%$ & $0.59 \%$ & $0.16 \%$ & $0.18 \%$ & $0.18 \%$ \\
\hline Max & $2.90 \%$ & $2.47 \%$ & $2.90 \%$ & $2.14 \%$ & $2.00 \%$ & $1.94 \%$ & $1.71 \%$ \\
\hline Standard Dev & 0.55 & 0.61 & 0.71 & 0.35 & 0.47 & 0.39 & 0.29 \\
\hline ACQPREM mean & $54.60 \%$ & $49.87 \%$ & $63.10 \%$ & $56.99 \%$ & $56.74 \%$ & $45.30 \%$ & $52.59 \%$ \\
\hline Min & $-16.19 \%$ & $-16.19 \%$ & $9.89 \%$ & $0.00 \%$ & $9.47 \%$ & $4.23 \%$ & $9.38 \%$ \\
\hline Max & $336.36 \%$ & $200.00 \%$ & $124.26 \%$ & $336.36 \%$ & $264.08 \%$ & $101.60 \%$ & $117.80 \%$ \\
\hline Standard Dev & 40.86 & 41.55 & 31.22 & 57.12 & 43.54 & 28.22 & 25.70 \\
\hline
\end{tabular}

In Table [2.2a], the mean IBFEE is higher for smaller transactions. That finding is consistent with Calomiris and Himmelberg (2004), and others, who find that investment banking fees for securities offerings tend to be higher for smaller, riskier firms, and also reflects a minimum fee charged by investment bankers on any transaction. Inasmuch as in the acquisition context the fee is expressed as a percentage of transaction value, higher 
Fee Dollar Amount increases with transaction size. While the mean ACQPREM varies

by target category, its standard deviation is much lower for the largest target categories.

Table [2.2b] shows that the largest transactions understandably involve the largest

firms, and that the volatility of stock price returns tends to be lower for the largest firms.

Large firms also tend to show fewer transactions where block shareholders other than

officers and directors own large stakes in the firm, a fact that reflects the higher costs of

foregoing diversification when holding a substantial share of a large firm. Across most

categories of transaction value targets tended to be in industries whose stocks generally

performed at least as well as the broader market, with the smallest firms exhibiting the

lowest standard deviation.

Table 2.2b: Target Characteristics

\begin{tabular}{|l|c|c|c|c|c|c|c|}
\hline $\begin{array}{l}\text { Variable/Transaction } \\
\text { Value }\end{array}$ & $\begin{array}{c}\text { Sample } \\
\text { Statistics }\end{array}$ & $\begin{array}{c}\$ 100- \\
\$ 149\end{array}$ & $\begin{array}{c}\$ 150- \\
\$ 199\end{array}$ & $\begin{array}{c}\$ 200- \\
\$ 299\end{array}$ & $\begin{array}{c}\$ 300- \\
\$ 499\end{array}$ & $\begin{array}{c}\$ 500- \\
\$ 999\end{array}$ & $\begin{array}{c}\$ 1,000 \text { and } \\
\text { Above }\end{array}$ \\
\hline $\begin{array}{l}\text { Number of } \\
\text { observations (N) }\end{array}$ & 170 & 36 & 29 & 33 & 31 & 19 & 22 \\
\hline Size (\$MM) mean & $\$ 320.42$ & $\$ 89.40$ & $\$ 122.06$ & $\$ 168.91$ & $\$ 236.71$ & $\$ 490.94$ & $\$ 1,157.88$ \\
\hline Min & $\$ 7.30$ & $\$ 7.30$ & $\$ 40.50$ & $\$ 32.40$ & $\$ 15.10$ & $\$ 45.50$ & $\$ 176.00$ \\
\hline Max & $\$ 3,060.40$ & $\$ 268.90$ & $\$ 362.40$ & $\$ 1,050.10$ & $\$ 1,078.00$ & $\$ 1,999.20$ & $\$ 3,060.40$ \\
\hline Standard Dev & 505.36 & 52.45 & 74.87 & 175.95 & 235.65 & 483.28 & 873.63 \\
\hline Vol mean & 0.64 & 0.64 & 0.69 & 0.64 & 0.67 & 0.58 & 0.60 \\
\hline Min & 0.17 & 0.29 & 0.27 & 0.31 & 0.20 & 0.17 & 0.19 \\
\hline Max & 1.63 & 1.42 & 1.46 & 1.33 & 1.63 & 1.20 & 1.50 \\
\hline Standard Dev & 0.26 & 0.23 & 0.30 & 0.22 & 0.28 & 0.25 & 0.30 \\
\hline Leverage mean & 0.13 & 0.13 & 0.13 & 0.11 & 0.12 & 0.16 & 0.14 \\
\hline Min & 0.00 & 0.00 & 0.00 & 0.00 & 0.00 & 0.00 & 0.00 \\
\hline Max & 0.92 & 0.65 & 0.49 & 0.92 & 0.60 & 0.76 & 0.65 \\
\hline Standard Dev & 0.18 & 0.16 & 0.15 & 0.19 & 0.19 & 0.21 & 0.17 \\
\hline PeerBroad mean & 0.99 & 0.90 & 0.94 & 0.91 & 1.10 & 0.85 & 1.27 \\
\hline Min & 0.13 & 0.33 & 0.13 & 0.29 & 0.49 & 0.23 & 0.46 \\
\hline Max & 3.04 & 2.51 & 2.07 & 1.85 & 3.04 & 1.44 & 2.90 \\
\hline Standard Dev & 0.49 & 0.42 & 0.43 & 0.40 & 0.55 & 0.35 & 0.71 \\
\hline Non-O/D_w/5\% mean & 2.49 & 3.25 & 2.79 & 2.33 & 2.06 & 2.05 & 2.05 \\
\hline Min & 0 & 0 & 0 & 0 & 0 & 0 & 0 \\
\hline Max & 7 & 6 & 7 & 7 & 4 & 4 & 5 \\
\hline Standard Dev & 1.57 & 1.59 & 1.72 & 1.63 & 1.39 & 1.18 & 1.40 \\
\hline O/D_Oship mean & $19.28 \%$ & $25.44 \%$ & $20.30 \%$ & $19.39 \%$ & $22.40 \%$ & $13.20 \%$ & $8.51 \%$ \\
\hline Min & $0.00 \%$ & $1.10 \%$ & $1.10 \%$ & $0.00 \%$ & $1.20 \%$ & $2.60 \%$ & $1.00 \%$ \\
\hline Max & $81.70 \%$ & $79.80 \%$ & $73.30 \%$ & $60.50 \%$ & $81.70 \%$ & $37.57 \%$ & $40.86 \%$ \\
\hline Standard Dev & 17.86 & 19.58 & 17.22 & 17.20 & 22.19 & 9.13 & 8.49 \\
\hline & & & & & & &
\end{tabular}


Table [2.2c] reports transaction characteristics of targets. In 102 of the 170 observations, either an auction was employed or multiple indications of interest were received (ModeSale=1). Clearly, in many cases there are multiple potential bidders for a target. That fact is significant for our analysis since, as discussed in Section 1, the potential for more than one bidder gives the investment banker receiving a Contingent Fee a greater incentive not to render a fairness opinion with respect to an otherwise financially inadequate offer. In 31 of the 170 transactions, the opinion of the investment bank indicated that the investment bank did not solicit additional bids (NoSolicitation=1).

Table 2.2c: Transaction Characteristics

\begin{tabular}{|l|c|c|c|c|c|c|}
\hline $\begin{array}{l}\text { Variable/Sample } \\
\text { Statistics }\end{array}$ & $\mathrm{N}=1$ & $\mathrm{~N}=0$ & $\begin{array}{c}\text { Mean } \\
\text { ACQPREM } \\
\mathrm{N}=1\end{array}$ & $\begin{array}{c}\text { Mean } \\
\text { ACQPREM } \\
\mathrm{N}=0\end{array}$ & $\begin{array}{c}\text { Standard } \\
\text { Deviation } \\
\mathrm{N}=1 /(\mathrm{SE})\end{array}$ & $\begin{array}{c}\text { Standard } \\
\text { Deviation } \\
\mathrm{N}=0 /(\mathrm{SE})\end{array}$ \\
\hline ModeSale & 102 & 68 & $55.04 \%$ & $53.94 \%$ & $47.86 /(4.74)$ & $27.54 /(3.34)$ \\
\hline NoSolicitation & 31 & 139 & $53.17 \%$ & $54.92 \%$ & $27.71 /(4.98)$ & $43.33 /(3.68)$ \\
\hline IBOthBus(Acquiror) & 30 & 140 & $53.42 \%$ & $54.85 \%$ & $29.96 /(5.47)$ & $42.92 /(3.63)$ \\
\hline IBOthBus(Target) & 28 & 142 & $58.03 \%$ & $53.93 \%$ & $26.83 /(5.07)$ & $43.14 /(3.62)$ \\
\hline Bonus & 24 & 146 & $57.21 \%$ & $54.17 \%$ & $21.41 /(4.37)$ & $43.27 /(3.58)$ \\
\hline EmpContr & 80 & 90 & $61.14 \%$ & $48.80 \%$ & $50.29 /(5.62)$ & $29.21 /(3.08)$ \\
\hline ShrhAgmt & 105 & 65 & $57.95 \%$ & $49.20 \%$ & $42.14 /(4.11)$ & $38.42 /(4.77)$ \\
\hline FixedFee_Pct & 53 & 65 & $50.54 \%$ & $58.86 \%$ & $51.80 /(7.12)$ & $37.46 /(4.65)$ \\
\hline Fixed_Pct_ExAnte & 53 & 65 & $55.66 \%$ & $58.86 \%$ & $51.65 /(7.10)$ & $37.46 /(4.65)$ \\
\hline
\end{tabular}

\begin{tabular}{|l|c|c|c|c|c|c|c|}
\hline $\begin{array}{l}\text { Variable/Transaction } \\
\text { Value }\end{array}$ & $\begin{array}{c}\text { Sample } \\
\text { Statistics }\end{array}$ & $\begin{array}{c}\$ 100- \\
\$ 149\end{array}$ & $\$ 150-\$ 199$ & $\$ 200-\$ 299$ & $\$ 300-\$ 499$ & $\$ 500-\$ 999$ & $\begin{array}{c}\$ 1,000 \\
\text { and } \\
\text { Above }\end{array}$ \\
\hline $\begin{array}{l}\text { Number of } \\
\text { observations (N) }\end{array}$ & 170 & 36 & 29 & 33 & 31 & 19 & 22 \\
\hline IB_Rank mean & 11.96 & 14.86 & 14.28 & 12.23 & 12.58 & 10.34 & 4.27 \\
\hline Min & 1.00 & 1.33 & 1.33 & 1.33 & 1.00 & 1.33 & 1.33 \\
\hline Max & 20.00 & 20.00 & 20.00 & 20.00 & 20.00 & 20.00 & 15.67 \\
\hline Standard Dev & 7.45 & 6.93 & 7.16 & 7.41 & 7.09 & 6.85 & 4.07 \\
\hline
\end{tabular}

Notes: $\mathrm{N}=1$ indicates transaction observations possessing characteristic noted and $\mathrm{N}=0$ indicates transaction observations lacking characteristic noted. In the case of FixedFee_Pct and Fixed_Pct_ExAnte, N=1 is the 53 observations with the highest FixedFee_Pct and N=0 is the 65 observations with zero fixed fees. Fixed_Pct_ExAnte is calculated as the ratio of the fixed part of investment bank's fee relative to the total fee, assuming that the acquisition value equals the pre-acquisition value of the target plus the sample average acquisition premium. 
Some deal attributes are associated with economically large differences in mean acquisition premia shown in Table [2.2c.], but only one of these differences is highly significant statistically. Transactions in which target managers entered into an employment contract with the acquiror in connection with the transaction display higher acquisition premia (61.14\% compared with $48.80 \%)$. This mean difference is statistically significant at the $2.8 \%$ level (for a one-tailed test). In contrast, differences in mean acquisition premia in transactions in which target managers received a bonus payment from the target company (other than golden parachute payments) related to successful consummation of transaction are neither economically large (57.21\% compared with $54.17 \%$ ) nor statistically significant. Greater target shareholder support as evidenced by the existence of a shareholder agreement is associated with a higher acquisition premium (57.95\% compared with $49.20 \%$ ), but this mean difference is less statistically significant (at the $8.3 \%$ level for a one-tailed test).

The FixedFee_Pct variable is defined as the percentage of the target investment banker's fee that is not contingent on the outcome of the transaction. Details regarding the distribution of this variable appear in Table [2.2d], which divides the sample (roughly) into three terciles according to the degree of fixity of the fee (65 firms with no fixity, and the remaining 105 firms divided into 52 middling-fixity firms and 53 highfixity firms). Transactions in the upper tercile of the fixity of investment banker fees (the top 53 firms measured according to FixedFee_Percent) tend to show lower acquisition premia, but this difference relative to the mean for firms with zero fixity is not statistically significant. Differences in mean acquisition premia related to prior relationships between the investment bank and the target or acquiror are not statistically 
significant and in the case of the existence of a prior relationship with the acquiror the mean acquisition premium difference is less than $2.0 \%$.

The statistically insignificant mean difference for FixedFee_Percent is opposite in sign to the difference implied by the jaundiced view, and we can think of no explanation for this observed difference. When we redefine the FixedFee_Percent variable using an ex ante measure (i.e., Fixed_Pct_ExAnte, which removes the effect of unanticipatedly high acquisition premia on the measured ratio), the difference in the means is substantially reduced. ${ }^{4}$ That finding indicates that the statistically insignificant difference in acquisition premia for deals with different FixedFee_Percent reported in Table [2.2c] may reflect correlation by construction, given that the denominator of the FixedFee_Percent variable is a positive function of the acquisition premium.

The simple differences in means shown in Table [2.2c] do not control for other attributes of targets or transactions (something we explore in the regression analysis in Section 3), and they are not necessarily indicative of causal relationships. Nevertheless, despite these limitations, the facts about mean differences suggest two important things: (a) on average, greater fixity in investment banker fees is not associated with higher acquisition premia (contrary to the jaundiced view), and (b) there are interesting patterns of association relating transactions and target characteristics to IBFEE and ACQPREM. Section 3 explores those patterns of association in the context of simple regression analyses.

\footnotetext{
${ }^{4}$ Fixed_Pct_ExAnte is calculated as the ratio of the fixed part of investment bank's fee relative to the total fee, assuming that the acquisition value equals the pre-acquisition value of the target plus the sample average acquisition premium. Details on the distribution of Fixed_Pct_ExAnte are provided in Table [2.2e].
} 
Table [2.2d]: Investment Banker Fee Structure

\begin{tabular}{|l|c|c|c|c|}
\hline Variable/FixedFee_Pct & $\begin{array}{c}\text { Entire } \\
\text { Sample }\end{array}$ & $\begin{array}{c}\text { Low } \\
\text { FixedFee_Pct }\end{array}$ & $\begin{array}{c}\text { Mid } \\
\text { FixedFee_Pct }\end{array}$ & $\begin{array}{c}\text { High } \\
\text { FixedFee_Pct }\end{array}$ \\
\hline Number of Deals & 170 & 65 & 52 & 53 \\
\hline $\begin{array}{l}\text { Retainer+Opn Fee mean } \\
\text { Total Fee }\end{array}$ & $15.75 \%$ & $0.00 \%$ & $8.77 \%$ & $41.90 \%$ \\
\hline Min & $0.00 \%$ & $0.00 \%$ & $0.68 \%$ & $17.24 \%$ \\
\hline Max & $100.00 \%$ & $0.00 \%$ & $17.05 \%$ & $100.00 \%$ \\
\hline Standard Dev & 0.24 & 0.00 & 0.05 & 0.28 \\
\hline $\begin{array}{l}\text { FixedFee Fee Dollar } \\
\text { Amount (\$MM) mean }\end{array}$ & $\$ 0.36$ & $\$ 0.00$ & $\$ 0.36$ & $\$ 0.79$ \\
\hline Min & $\$ 0.00$ & $\$ 0.00$ & $\$ 0.04$ & $\$ 0.08$ \\
\hline Max & $\$ 4.00$ & $\$ 0.00$ & $\$ 2.50$ & $\$ 4.00$ \\
\hline Standard Dev & 0.59 & 0.00 & 0.38 & 0.81 \\
\hline $\begin{array}{l}\text { Total Fees Dollar Amount } \\
\text { \$MM) mean }\end{array}$ & $\$ 4.24$ & $\$ 5.05$ & $\$ 4.83$ & $\$ 2.69$ \\
\hline Min & $\$ 0.15$ & $\$ 0.25$ & $\$ 0.88$ & $\$ 0.15$ \\
\hline Max & $\$ 25.21$ & $\$ 25.21$ & $\$ 21.00$ & $\$ 23.00$ \\
\hline Standard Dev & 4.46 & 4.86 & 4.42 & 3.58 \\
\hline Average Deal Size $(\$ M M)$ & $\$ 553.33$ & $\$ 666.22$ & $\$ 524.98$ & $\$ 442.69$ \\
\hline Min & $\$ 100.04$ & $\$ 119.88$ & $\$ 105.22$ & $\$ 100.04$ \\
\hline Max & $\$ 5,602.99$ & $\$ 5,602.99$ & $\$ 3,840.94$ & $\$ 4,062.68$ \\
\hline Standard Dev & 818.74 & 969.11 & 722.20 & 694.21 \\
\hline ACQPREM mean & $54.60 \%$ & $58.86 \%$ & $53.42 \%$ & $50.54 \%$ \\
\hline Min & $-16.19 \%$ & $-16.19 \%$ & $-13.92 \%$ & $-6.80 \%$ \\
\hline Max & $336.36 \%$ & $264.08 \%$ & $117.80 \%$ & $336.36 \%$ \\
\hline Standard Dev & 40.86 & 37.46 & 31.53 & 51.80 \\
\hline
\end{tabular}


Table [2.2e]: Investment Banker Fee Structure

\begin{tabular}{|l|c|c|c|c|}
\hline Variable/Fixed_Pct_ExAnte & $\begin{array}{c}\text { Entire } \\
\text { Sample }\end{array}$ & $\begin{array}{c}\text { Low } \\
\text { Fixed_Pct_- } \\
\text { ExAnte }\end{array}$ & $\begin{array}{c}\text { Mid } \\
\text { Fixed_Pct_ } \\
\text { ExAnte }\end{array}$ & $\begin{array}{c}\text { High } \\
\text { Fixed_Pct_ } \\
\text { ExAnte }\end{array}$ \\
\hline Number of Deals & 170 & 65 & 52 & 53 \\
\hline $\begin{array}{l}\text { Retainer+Opn Fee mean } \\
\text { Total Fee }\end{array}$ & $15.75 \%$ & $0.00 \%$ & $9.05 \%$ & $41.63 \%$ \\
\hline Min & $0.00 \%$ & $0.00 \%$ & $0.68 \%$ & $13.23 \%$ \\
\hline Max & $100.00 \%$ & $0.00 \%$ & $22.73 \%$ & $100.00 \%$ \\
\hline Standard Dev & 0.24 & 0.00 & 0.06 & 0.28 \\
\hline $\begin{array}{l}\text { FixedFee Fee Dollar } \\
\text { Amount (\$MM) mean }\end{array}$ & $\$ 0.36$ & $\$ 0.00$ & $\$ 0.38$ & $\$ 0.77$ \\
\hline Min & $\$ 0.00$ & $\$ 0.00$ & $\$ 0.04$ & $\$ 0.08$ \\
\hline Max & $\$ 4.00$ & $\$ 0.00$ & $\$ 2.50$ & $\$ 4.00$ \\
\hline Standard Dev & 0.59 & 0.00 & 0.39 & 0.82 \\
\hline $\begin{array}{l}\text { Total Fees Dollar Amount } \\
\text { \$MM) mean }\end{array}$ & $\$ 4.24$ & $\$ 5.05$ & $\$ 4.90$ & $\$ 2.62$ \\
\hline Min & $\$ 0.15$ & $\$ 0.25$ & $\$ 0.88$ & $\$ 0.15$ \\
\hline Max & $\$ 25.21$ & $\$ 25.21$ & $\$ 21.00$ & $\$ 23.00$ \\
\hline Standard Dev & 4.46 & 4.86 & 4.41 & 3.55 \\
\hline Average Deal Size $(\$ M M)$ & $\$ 553.33$ & $\$ 666.22$ & $\$ 549.68$ & $\$ 418.46$ \\
\hline Min & $\$ 100.04$ & $\$ 119.88$ & $\$ 105.22$ & $\$ 100.04$ \\
\hline Max & $\$ 5,602.99$ & $\$ 5,602.99$ & $\$ 3,840.94$ & $\$ 4.062 .68$ \\
\hline Standard Dev & 818.74 & 969.11 & 725.37 & 687.14 \\
\hline ACQPREM mean & $54.60 \%$ & $58.86 \%$ & $48.20 \%$ & $55.66 \%$ \\
\hline Min & $-16.19 \%$ & $-16.19 \%$ & $-13.92 \%$ & $4.23 \%$ \\
\hline Max & $336.36 \%$ & $264.08 \%$ & $117.80 \%$ & $336.36 \%$ \\
\hline Standard Dev & 40.86 & 37.46 & 31.39 & 51.65 \\
\hline & & & & \\
\hline
\end{tabular}

\section{Regression Analysis}

In Section 1.4, we developed six testable implications of the benign and jaundiced views. In Section 3, we construct simple regression models of IBFEE and ACQPREM to investigate those implications. Table 3.1 summarizes the six implications on which we focus. 
Table 3.1: Predictions of Benign and Jaundiced Views

\begin{tabular}{|l|c|c|}
\hline & Benign View & Jaundiced View \\
\hline 1. IBFEE reflects information cost & $*$ & \\
\hline 2. Complicated transactions have higher IBFEE & $*$ & \\
\hline 3. IBFEE falls as FixedFee_Percent rises & $*$ & \\
\hline 4. ACQPREM reflects franchise value of target & $*$ & \\
\hline 5. ACQPREM rises with FixedFee_Percent & & $*$ \\
\hline 6. Relationship with acquiror reduces ACQPREM & & $*$ \\
\hline
\end{tabular}

\subsection{Determinants of the Investment Banker Fee (IBFEE)}

In constructing a simple model that explains cross-sectional variation in IBFEE, we take into account various proxies for the influences referred to in the first three rows of Table [3.1]. Regression results are reported in Table [3.2].

The definition of the dependent variable in Table [3.2] is a transformed version of IBFEE, which we label IBFEE_EXANTE. This transformation of IBFEE uses the expected transaction value for the target rather than the actual transaction value in the denominator of the fee percentage calculation. The expected transaction value simply adds the sample average of the acquisition premium (55\%) to the pre-acquisition equity value of the target and adds the result to the implied book value of the target debt to arrive at the expected transaction value. This transformation avoids spurious inferences about association between IBFEE and the regressors, which could result from a correlation between the error term in IBFEE (related to unpredictably high premia) and 
the regressors. As discussed in Section 2, the percentage of fixed fee should be similarly adjusted to avoid spurious correlation; consequently, Fixed_Pct_ExAnte is the regressor used to capture the degree of fixity of fees. We also ran the same regressions as reported in Table [3.2] without making these two ex ante adjustments and obtained very similar results.

With respect to the first hypothesis in Table [3.1], as proxies for information cost specific to the target firm, we included firm asset size (modeled using a quadratic functional form), the volatility of stock price returns, leverage, and whether the target had a prior fee producing relationship with the investment bank. IBFEE should be higher for targets that are small firms, firms with higher returns volatility, highly leveraged firms, and firms that have not had previous contact with the investment bank. PeerBroad is included to capture the effects of hot markets for a particular industry's targets. We anticipated that IBFEE should be lower for target's in industries where the industry is outperforming the broader market.

With respect to the second hypothesis, NoSolicitation is included, and we expect it to enter with a negative sign. That is, when an investment bank's engagement does not entail the solicitation of additional bidders, the fee charged by the investment bank should be lower.

With respect to the third hypothesis, FixedFee_Percent is expected to display a negative coefficient. Note that the variable included in the regression is Fixed_Pct_ExAnte rather than FixedFee_Percent. Fixed_Pct_ExAnte calculates the fixity percentage of the fee based on the expected transaction value rather than the actual transaction value for the target. 
We also included IBOtherBus(Acquiror) in the IBFEE_EXANTE regression, and IB_Rank, to investigate whether fees are related to the rank of the investment bank or the relationship between the acquiror and the target's investment bank. To measure IB_Rank, we constructed a league table ranking for each investment bank. Banks were assigned a rank (one through 20 with lower rankings associated with a greater participation by the bank in announced M\&A transactions) based on the individual bank's rank in announced M\&A transactions as reported by Investment Dealers Digest. Banks that did not appear on the Investment Dealers Digest league table for a given year were assigned a rank of 20. The rank so assigned for each year was then averaged over the three year period based on the three years prior to the announcement of the transaction. ${ }^{5}$

We report five regression specifications in Table [3.2]. Our results for the IBFEE regressions support all three of the predictions of the benign view, although not all the variables included are highly statistically significant.

Consistent with hypothesis one (the benign view), when evaluated over the range of our sample, asset size (in its quadratic form) is negatively related to investment banking fees. A similar result has been reported by McLaughlin (1990) in her work on investment banking contracts in tender offers. McLaughlin analyzed all fees in tender offers for all types of transactions and for fees paid to target firm bankers over the period January 1980 to December 1985. McLaughlin reported (1) a mean fee as a percentage of transaction value of 0.77 with a standard deviation of 0.63 , and (2) a mean fee expressed in dollars of $\$ 4.21$ million with a standard deviation of 2.50. Consistent with our findings

\footnotetext{
${ }^{5}$ Sixteen observations in the sample reported multiple advisors to the target. In these instances the average of the advisor ranks was used and the fee was based on the fee paid to all investment banks. In certain of these sixteen observations an advisor may have been retained to render only an opinion - what has been recently referred to as a "second opinion." See Wall Street Journal, January 24, 2005. We ran our regression results removing these sixteen observations and obtained very similar results.
} 
in Table [3.2], McLaughlin also observed substantial cross-sectional variation in each category of offer value suggesting that there is substantial negotiation involved between the banker and the target firm in setting the fee. In other words, size is not the only characteristic that matters; the banker does not use a simple "rate card" such as the socalled "Lehman formula" wherein the fee is determined solely by a decreasing step function of the value of the transaction (e.g., $5 \%, 4 \%, 3 \%, 2 \%$, or $1 \%$ of various increments in transaction value).

Similarly, leverage and volatility enter positively in the fee regression. Other business between the target and the bank has a negative effect on the fee, as predicted, but this effect is not highly statistically significant (with a significance level of roughly 12 percent). PeerBroad enters negatively, as predicted, and is highly statistically significant.

Consistent with hypothesis two (the benign view), NoSolicitation enters negatively. Consistent with hypothesis three of the benign view, the degree of fixity of the fee is negatively related to the size of the fee, reflecting the compensation received by investment bankers in the form of a higher fee when their fee is riskier (i.e., more contingent).

IBOthBus(Acquiror) is small, negative, and statistically insignificant. IB_Rank is negative and statistically significant. Consistent with our expectation, an investment bank with more transaction experience (a lower rank) in the M\&A field is able to command a higher premium for its services, all other factors held constant. 
Table 3.2

Investment Bank Fee (IBFEE_EXANTE) Regressions (Significance Levels in Parentheses)
(1)
(2)
(3)
(4)
(5)

\begin{tabular}{|c|c|c|c|c|c|}
\hline Constant & $\begin{array}{c}0.434 \\
(0.482)\end{array}$ & $\begin{array}{c}0.700 \\
(0.260)\end{array}$ & $\begin{array}{c}0.434 \\
(0.484)\end{array}$ & $\begin{array}{c}0.776 \\
(0.211)\end{array}$ & $\begin{array}{c}0.802 \\
(0.198)\end{array}$ \\
\hline Ln (Size) & $\begin{array}{c}0.402 \\
(0.073)\end{array}$ & $\begin{array}{c}0.395 \\
(0.075)\end{array}$ & $\begin{array}{c}0.402 \\
(0.074)\end{array}$ & $\begin{array}{c}0.357 \\
(0.108)\end{array}$ & $\begin{array}{c}0.355 \\
(0.110)\end{array}$ \\
\hline$[\operatorname{Ln}(\text { Size })]^{2}$ & $\begin{array}{l}-0.053 \\
(0.010)\end{array}$ & $\begin{array}{l}-0.056 \\
(0.006)\end{array}$ & $\begin{array}{l}-0.053 \\
(0.011)\end{array}$ & $\begin{array}{l}-0.052 \\
(0.012)\end{array}$ & $\begin{array}{l}-0.051 \\
(0.013)\end{array}$ \\
\hline PeerBroad & $\begin{array}{l}-0.213 \\
(0.003)\end{array}$ & $\begin{array}{l}-0.232 \\
(0.001)\end{array}$ & $\begin{array}{l}-0.213 \\
(0.004)\end{array}$ & $\begin{array}{l}-0.226 \\
(0.002)\end{array}$ & $\begin{array}{l}-0.215 \\
(0.003)\end{array}$ \\
\hline Vol & $\begin{array}{c}0.499 \\
(0.000)\end{array}$ & $\begin{array}{c}0.480 \\
(0.000)\end{array}$ & $\begin{array}{c}0.499 \\
(0.000)\end{array}$ & $\begin{array}{c}0.502 \\
(0.000)\end{array}$ & $\begin{array}{c}0.502 \\
(0.000)\end{array}$ \\
\hline Leverage & $\begin{array}{c}0.582 \\
(0.011)\end{array}$ & $\begin{array}{c}0.659 \\
(0.004)\end{array}$ & $\begin{array}{c}0.581 \\
(0.013)\end{array}$ & $\begin{array}{c}0.625 \\
(0.007)\end{array}$ & $\begin{array}{c}0.609 \\
(0.008)\end{array}$ \\
\hline NoSolicitation & $\begin{array}{l}-0.301 \\
(0.001)\end{array}$ & $\begin{array}{l}-0.322 \\
(0.000)\end{array}$ & $\begin{array}{l}-0.302 \\
(0.001)\end{array}$ & $\begin{array}{l}-0.312 \\
(0.001)\end{array}$ & $\begin{array}{l}-0.328 \\
(0.000)\end{array}$ \\
\hline Fixed_Pct_ExAnte & $\begin{array}{l}-0.801 \\
(0.000)\end{array}$ & $\begin{array}{l}-0.751 \\
(0.000)\end{array}$ & $\begin{array}{l}-0.802 \\
(0.000)\end{array}$ & $\begin{array}{l}-0.742 \\
(0.000)\end{array}$ & $\begin{array}{l}-0.759 \\
(0.000)\end{array}$ \\
\hline IB_Rank & & $\begin{array}{l}-0.012 \\
(0.022)\end{array}$ & & $\begin{array}{l}-0.011 \\
(0.025)\end{array}$ & $\begin{array}{l}-0.013 \\
(0.018)\end{array}$ \\
\hline IBOthBus(Acquiror) & & & $\begin{array}{l}-0.004 \\
(0.965)\end{array}$ & & $\begin{array}{l}-0.079 \\
(0.428)\end{array}$ \\
\hline IBOthBus(Target) & & & & $\begin{array}{l}-0.140 \\
(0.130)\end{array}$ & $\begin{array}{l}-0.141 \\
(0.126)\end{array}$ \\
\hline $\begin{array}{l}\text { Adj. R-Squared } \\
\text { No. Obs. }\end{array}$ & $\begin{array}{c}0.369 \\
170\end{array}$ & $\begin{array}{c}0.385 \\
170\end{array}$ & $\begin{array}{c}0.365 \\
170\end{array}$ & $\begin{array}{c}0.390 \\
170\end{array}$ & $\begin{array}{c}0.389 \\
170\end{array}$ \\
\hline
\end{tabular}

Notes: Dependent variable: IBFEE_EXANTE is the ratio of the investment bank's fee relative to the pre-acquisition value of the target plus the sample average acquisition premium. 


\subsection{Determinants of the Acquisition Premium}

In constructing a simple model that explains cross-sectional variation in ACQPREM, we take into account various proxies for the influences referred to in the last three rows of Table [3.1], as well as a variety of control variables that previous literature suggests may be relevant for explaining acquisition premia. Regression results are reported in Table [3.3].

With respect to hypothesis four (benign view) in Table [3.1], we include EmpContr to measure the extent to which there is perceived franchise value to the target associated with the acquiror's decision to contract to retain target management.

With respect to hypothesis five, we include Fixed_Pct_ExAnte. According to the jaundiced view, more fixity avoids conflicts of interest, and therefore, should result in higher acquisition premia, all else held constant.

With respect to hypothesis six, IBOthBus(Acquiror) should enter negatively, since according to the jaundiced view, investment banks might be suborned by their contacts with acquirors, resulting in lower acquisition premia for targets.

We also include several other control variables. Controls that were not included in the fee regressions include measures of the concentration of stock ownership, which we thought might be relevant for acquisition premia (since greater concentration might improve the bargaining power of target shareholders). Similarly, we include a dummy variable for the presence of a voting agreement between the acquiror and target shareholders, which should also reflect greater target bargaining power.

With respect to hypothesis four, EmpContr enters positively and is large economically, but it is not highly statistically significant (with a significance level 
ranging between 12 and 15 percent). The Bonus variable, in contrast, is negative and statistically insignificant. Recall that EmpContr reflects the existence of a contractual agreement between the acquiror and target management, while Bonus reflects a payment from the target to its management in connection with the consummation of the transaction. These results indicate that payments to management, per se, do not affect shareholder value, but that payments to retain management are possibly value-increasing. This finding provides some support for the view that acquisition premia reflect, in part, the value of intangible assets of target firms. This finding also suggests that target firm shareholders may share in the gains that accrue to target management from preserving value-creating managerial capital.

Neither of the two jaundiced-view hypotheses (five and six) receives support from the regression analysis of ACQPREM. Both the degree of fixity of the investment banker's fee, and the existence of a prior fee-producing business relationship between the acquiror and the target's investment bank, are unrelated to the acquisition premium.

Controls for volatility and leverage both entered positively in the acquisition premium regression. These variables could proxy for many influences (e.g., growth opportunities, more disciplined management) and are not amenable to clear interpretation. Interestingly, while none of the controls for target bargaining power (including the composition of shareholders, and the ShrhAgt variable) prove to be highly statistically significant, ShrhAgt and Non-O/D_w/5\% are both positive and sometimes significant at levels of 13 or $14 \%$, and the coefficient on ShrhAgt is large.

ModeSale proved insignificant. Of course, that does not imply that increased competition has no effect on the acquisition premium. Rather, it may be explained by 
noting that ModeSale is an endogenous variable. The desire on the part of the target to receive multiple bids itself results from an expectation that doing so will improve the outcome, and that improvement will be larger for some firms than for others. That endogeneity may have the effect of reducing the measured effect of ModeSale on the acquisition premium in our regressions; that is, ModeSale may be more likely to be positive when the target's acquisition premium without ModeSale would be particularly low.

Similarly, the fact that IBFEE_Res does not enter significantly in the ACQPREM regression should not be interpreted as evidence that spending more on investment banking services is worthless. IBFEE is a highly endogenous variable. As in the case of ModeSale, its insignificance in the ACQPREM regression can be explained by the supposition that firms with large unexplained investment banking costs have unobservable attributes (i.e., information problems) that encourage them to spend more. 
Table 3.3

Acquisition Premium (ACQPREM) Regressions (Significance Levels in Parentheses)

(1)

(2)

(3)

(4)

(5)

(6)

\begin{tabular}{|c|c|c|c|c|c|c|}
\hline Constant & $\begin{array}{r}-20.106 \\
(0.337)\end{array}$ & $\begin{array}{r}-14.528 \\
(0.121)\end{array}$ & $\begin{array}{r}-14.407 \\
(0.130)\end{array}$ & $\begin{array}{r}-14.265 \\
(0.138)\end{array}$ & $\begin{array}{r}-14.369 \\
(0.127)\end{array}$ & $\begin{array}{l}-9.091 \\
(0.746)\end{array}$ \\
\hline Ln (Size) & $\begin{array}{c}0.077 \\
(0.980)\end{array}$ & & & & & $\begin{array}{l}-0.765 \\
(0.833)\end{array}$ \\
\hline ModeSale & $\begin{array}{c}4.882 \\
(0.381)\end{array}$ & & & & & $\begin{array}{c}4.052 \\
(0.504)\end{array}$ \\
\hline MarkAct & $\begin{array}{c}1.172 \\
(0.497)\end{array}$ & & & & & $\begin{array}{c}1.122 \\
(0.534)\end{array}$ \\
\hline Bonus & $\begin{array}{l}-4.353 \\
(0.581)\end{array}$ & & & & & $\begin{array}{l}-4.726 \\
(0.570)\end{array}$ \\
\hline EmpContr & $\begin{array}{c}8.503 \\
(0.120)\end{array}$ & $\begin{array}{c}7.887 \\
(0.141)\end{array}$ & $\begin{array}{c}7.868 \\
(0.149)\end{array}$ & $\begin{array}{c}7.857 \\
(0.144)\end{array}$ & $\begin{array}{c}7.896 \\
(0.142)\end{array}$ & $\begin{array}{c}8.149 \\
(0.152)\end{array}$ \\
\hline Non-O/D_w/5\% & $\begin{array}{c}2.160 \\
(0.227)\end{array}$ & $\begin{array}{c}2.522 \\
(0.141)\end{array}$ & $\begin{array}{c}2.535 \\
(0.143)\end{array}$ & $\begin{array}{c}2.526 \\
(0.142)\end{array}$ & $\begin{array}{c}2.449 \\
(0.158)\end{array}$ & $\begin{array}{c}2.050 \\
(0.280)\end{array}$ \\
\hline O/D_Oship & $\begin{array}{r}-18.654 \\
(0.279)\end{array}$ & & & & & $\begin{array}{r}-19.508 \\
(0.278)\end{array}$ \\
\hline ShrhAgt & $\begin{array}{c}9.130 \\
(0.132)\end{array}$ & $\begin{array}{c}6.474 \\
(0.238)\end{array}$ & $\begin{array}{c}6.453 \\
(0.244)\end{array}$ & $\begin{array}{c}6.509 \\
(0.237)\end{array}$ & $\begin{array}{c}6.541 \\
(0.235)\end{array}$ & $\begin{array}{c}8.858 \\
(0.154)\end{array}$ \\
\hline Vol & $\begin{array}{c}74.386 \\
(0.000)\end{array}$ & $\begin{array}{c}73.317 \\
(0.000)\end{array}$ & $\begin{array}{c}73.468 \\
(0.000)\end{array}$ & $\begin{array}{c}73.196 \\
(0.000)\end{array}$ & $\begin{array}{c}73.269 \\
(0.000)\end{array}$ & $\begin{array}{l}74.547 \\
(0.000)\end{array}$ \\
\hline Leverage & $\begin{array}{l}58.612 \\
(0.001)\end{array}$ & $\begin{array}{c}61.308 \\
(0.000)\end{array}$ & $\begin{array}{c}61.177 \\
(0.000)\end{array}$ & $\begin{array}{c}61.472 \\
(0.000)\end{array}$ & $\begin{array}{c}61.373 \\
(0.000)\end{array}$ & $\begin{array}{l}59.466 \\
(0.002)\end{array}$ \\
\hline IBOthBus(Acquiror) & & & $\begin{array}{l}-0.449 \\
(0.950)\end{array}$ & & & $\begin{array}{l}-1.730 \\
(0.835)\end{array}$ \\
\hline IBOthBus(Target) & & & $\begin{array}{l}-0.797 \\
(0.912)\end{array}$ & & & $\begin{array}{c}0.699 \\
(0.928)\end{array}$ \\
\hline Fixed_Pct_ExAnte & & & & $\begin{array}{l}-1.444 \\
(0.898)\end{array}$ & & $\begin{array}{c}0.972 \\
(0.937)\end{array}$ \\
\hline IBFEE_Res & & & & & $\begin{array}{c}1.978 \\
(0.758)\end{array}$ & $\begin{array}{c}0.922 \\
(0.890)\end{array}$ \\
\hline PeerBroad & & & & & & $\begin{array}{l}-2.118 \\
(0.739)\end{array}$ \\
\hline IB_Rank & & & & & & $\begin{array}{l}-0.273 \\
(0.536)\end{array}$ \\
\hline Adj. R-Squared & 0.278 & 0.289 & 0.280 & 0.284 & 0.285 & 0.253 \\
\hline No. Obs. & 170 & 170 & 170 & 170 & 170 & 170 \\
\hline
\end{tabular}

Notes: Dependent variable: ACQPREM is defined as offer price divided by target stock price minus one, using target stock price four weeks prior to announcement. IBFee_Res is the residual from regression (4) in Table [3.2]. 


\section{Conclusion}

Our investigation of investment banking fees for fairness opinions and acquisition premia is the first empirical analysis of friendly, two-step, cash acquisitions during our period of which we are aware. Our study is largely descriptive and we do not purport to produce a structural estimation of the determinants of investment banking fees or acquisition premia.

Nevertheless, our results are broadly consistent with the predictions of a benign view of the role of investment banks in advising acquisition targets. Fees to banks are correlated with attributes of transactions and target firms in ways that make sense if banks are being paid for processing information. The more contingent (and, therefore, risky) the fees, the higher they tend to be, all else held constant. Variation in acquisition premia also can be explained by fundamental deal attributes. For example, acquisition premia are higher when the target's leverage and volatility are higher, and (possibly) when the acquiror contractually seeks to retain target management. Contrary to the jaundiced view of fairness opinions, greater fixity of fees is not associated with higher acquisition premia, and there is no evidence that investment banks are suborned by acquirors with whom they have had a prior banking relationship. 


\section{References}

1. A. Davis and M. Langley, Opinions Labeling Deals 'Fair' Can be Far From Independent, Wall Street Journal, December 29, 2004, A1.

2. L. Bebchuk and M. Kahan, Fairness Opinions: How Fair are They and What Can be Done About It?, 27 Duke Law Journal 27, 53 (1989).

3. Investment Banker Liability: A Panel Discussion, 16 Del. J. Corp. Law 557, 574 (1991).

4. A. Raghavan, Artful Deal Advisers Look Beyond Quality, Wall Street Journal, December 11, 2003, C1.

5. NASD Notice to Members 04-83 Request for Comment on Whether to Propose New Rule That Would Address Conflicts of Interest When Members Provide Fairness Opinions in Corporate Control Transactions ("NASD Notice 04-83") available at www.nasdr.com.

6. Response of California Public Employees' Retirement System, February 1, 2005, to NASD Notice 04-83 available at www.nasdr.com.

7. Response of American Federation of Labor and Congress of Industrial Organizations, February 1, 2005, to NASD Notice 04-83 available at www.nasdr.com.

8. Response of The Association of the Bar of the City of New York, February 1, 2005, to NASD Notice 04-83 available at www.nasdr.com.

9. Response of Securities Industry Association, February 1, 2005, to NASD Notice 0483 available at www.nasdr.com.

10. A. Davis and D. Berman, Checkup Prompts Search for Second Opinions, Wall Street Journal, January 24, 2005, C1.

11. C. Calomiris and C. Himmelberg, Investment Banking Costs as a Measure of the Cost of Access to External Finance, Working Paper Columbia University (2004).

12. R. McLaughlin, 1990, Investment-Banking Contracts in Tender Offers-An Empirical Analysis, Journal of Financial Economics 209, 211-219. 